\title{
Screening of Nitrogen Fixing Endophytic Bacteria in Oryza sativa L.
}

\author{
Prathana Hongrittipun ${ }^{1}$, Somchit Youpensuk ${ }^{1} \&$ Benjavan Rerkasem ${ }^{2}$ \\ ${ }^{1}$ Department of Biology, Faculty of Science, Chiang Mai University, Chiang Mai, Thailand \\ ${ }^{2}$ Lanna Rice Research Centre, Chiang Mai University, Chiang Mai, Thailand \\ Correspondence: Somchit Youpensuk, Department of Biology, Faculty of Science, Chiang Mai University, \\ Chiang Mai 50200, Thailand. Tel: 66-053-943-346 ext. 143. E-mail: scboi027@chiangmai.ac.th
}

Received: March 3, 2014 Accepted: April 10, 2014 Online Published: May 15, 2014

doi:10.5539/jas.v6n6p66 URL: http://dx.doi.org/10.5539/jas.v6n6p66

\begin{abstract}
Nitrogen (N) is an essential element for the growth and yield of rice. Some endophytic bacteria can fix $\mathrm{N}_{2}$ from the air and convert to nitrogen compounds that can be utilized by plants. In this study, endophytic bacteria were isolated from one-month-old seedlings of five rice (Oryza sativa L.) varieties (Muey Nong 24, Muey Nong 25, Pathum Thani 1, Suphan Buri 1 and Chai Nat 1) growing without nitrogen fertilizer in the farmers' field. One hundred and twenty-three isolates of endophytic bacteria were obtained from the roots, stems and leaves of these rice varieties. Nitrogenase activity of the bacteria in $\mathrm{N}$-free culture medium was determined by acetylene reduction assay. Seven isolates of the bacteria with highest nitrogenase activity were identified by phylogenetic analysis of the 16S rRNA genes, and found to belong to Burkholderia cepacia (CS5), Citrobacter sp. (CR9), Citrobacter sp. (SS5), Citrobacter sp. (SS6), Bacillus amyloliquefaciens (25R14), B. amyloliquefaciens (SR1) and B. thuringiensis (25R2). Inoculation of Bu. cepacia (CS5) and Citrobacter sp. (CR9) to the seedlings of local rice variety (Muey Nong 24) significantly increased nitrogen concentration in the roots of rice.
\end{abstract}

Keywords: endophytic bacteria, nitrogen fixation, Oryza sativa L.

\section{Introduction}

Rice is the most important crop in Asia as the main staple food and to those who depend on rice farming for their livelihoods. Nitrogen is the most important nutrient in rice production. It is the primary input in modern rice farming (Craswell et al., 1981; Yoshida, 1981). Large amounts of nitrogen fertilizer, amounting to 112 million tons a year are used [globally in 2009 to 2011 (FAOSTAT, 2013)] in cultivation of rice and other economic crops. However, a notable exception is the commercial sugarcane production in Brazil which uses only limited input of $\mathrm{N}$ fertilizer and rely mainly on fixation of $\mathrm{N}_{2}$ from the atmosphere by endophytic bacteria (Boddey et al., 2003). Subsistence rice production in Thailand is also rarely given any fertilizer. Economic crops, including rice, maize, wheat, sorghum and sugarcane have been reported to harbor endophytic bacteria that can convert $\mathrm{N}_{2}$ from the atmosphere into combined $\mathrm{N}$ that can be utilized by plants while having no pathogenic effect on them (James et al., 1997; Bhattacharjee et al., 2008; Lima et al., 1987). Endophytic bacteria that can fix $\mathrm{N}_{2}$ from the air are found in seeds, roots and stem of the rice plant include Azoarcus sp., Herbaspirillum seropedicae, Bacillus megaterium, Azosprillium, Sphingomonas paucimobilis, Pantoea agglomerans, Idenella dechloratans and Burkholderia cepacia (Stolzfus et al., 1997; Engelhard et al., 2000; Gyaneshwar et al., 2001; Jame et al., 2002). Inoculation of rice plants with $\mathrm{N}_{2}$ fixing endophytic bacteria has resulted in increased growth and yield. Nitrogen fixing endophytic bacteria inoculation of rice seedlings has been shown to significantly increase biomass and grain yield of rice included Gluconacetobacter diazotrophicus, Serratia marcescens, Burkholderia sp. and Azoarcus sp. (Bhattacharjee et al., 2008; Choudhury \& Kennedy, 2004). There is a possibility that endophytic $\mathrm{N}_{2}$-fixing bacteria might play an important role in maintaining the yield of wetland rice in the mountains of northern Thailand without fertilizer input. This study was set out to (1) isolate endophytic $\mathrm{N}_{2}$ fixing bacteria from rice plants grown without $\mathrm{N}$ fertilizer, (2) identify the bacteria selected on the basis of their $\mathrm{N}_{2}$-fixing capacity and (3) evaluate the effect of selected bacteria on the growth of rice seedlings.

\section{Method}

\subsection{Isolation of Endophytic Bacteria From Rice}

Endophytic bacteria were isolated from 4 week-old seedlings of five rice varieties (local varieties Muey Nong 24 and Muey Nong 25, and modern varieties Pathum Thani 1, Suphan Buri 1 and Chai Nat 1) growing in farmers' 
fields at the highland village of Thung Luang, in Mae Wang district of Chiang Mai (Lat. 18 $40^{\circ}$; Long. $98^{\circ} 35^{\prime}$; Alt. $865 \mathrm{~m}$ ) which had never received any fertilizer. The rice plant samples were washed with tap water and placed in $1.2 \% \mathrm{NaOCl}$ for $5 \mathrm{~min}$ and immediately washed twice in sterile distilled water. The samples were then ground in a mortar. Serial ten fold dilutions of the ground samples were done with $0.85 \% \mathrm{NaCl}$ solution. The suspension diluted to $10^{-1}-10^{-6}$ were spread on nitrogen free agar (NFA) plates, and incubated at $30^{\circ} \mathrm{C}$ for 3-7 days. The bacterial isolates on NFA were streaked and single colonies re-streaked on NFA for pure culture collection.

\subsection{Determination of Nitrogenase Activity}

Nitrogenase activity of the endophytic bacteria was examined by acetylene reduction assay (ARA) in $20 \mathrm{ml}$ capped tube containing $9 \mathrm{ml}$ of semisolid culture of NFA. The atmosphere in the capped tube was replaced with $10 \%$ acetylene $(\mathrm{v} / \mathrm{v})$ and incubated at $30^{\circ} \mathrm{C}$ for $24 \mathrm{~h}$. Ethylene formation was measured by gas chromatography. The nitrogenase activity was calculated in unit $\mathrm{nmol} \mathrm{C}_{2} \mathrm{H}_{4} / \mathrm{mg}$ protein/h (Lee \& Yoshida, 1997). The bacteria with highest nitrogenase activities were selected for identification.

\subsection{Effect of Nitrogen Fixing Bacteria on Rice}

The selected endophytic bacteria were tested for nitrogen fixation in rice variety Muey Nong 24. Seeds of the rice were surface sterilized in $1.2 \% \mathrm{NaOCl}$ for $5 \mathrm{~min}$, then washed three times with sterile distilled water. The seeds were placed on sterile wet tissue paper in Petri dish to germinate. The germinated seed was transferred to $\mathrm{N}$-free nutrient solution (McDonald et al., 2001) to grow for 10 days. The rice seedlings were then inoculated by immersing the rice roots in $9 \times 10^{8}$ cells $/ \mathrm{ml}$ bacterial suspension in $0.85 \% \mathrm{NaCl}$ for $60 \mathrm{~min}$. For un-inoculated control treatment, the rice roots were immersed in $0.85 \% \mathrm{NaCl}$ for $60 \mathrm{~min}$. The rice seedlings were transferred to pots containing $5 \mathrm{~L}$ of $\mathrm{N}$-free nutrient solution. After growing for 49 days, the rice plants were added with $9 \times 10^{10}$ cells $/ \mathrm{ml}$ bacterial suspension and $1 \%$ yeast extract. The un-inoculated control plants were given $1 \mathrm{ml}$ of $1 \%$ sterile yeast extract. Chlorophyll contents of the youngest emerged blade (YEB) were measured weekly with a chlorophyll meter (Minolta SPAD 502). The rice plants were harvested 84 days after the first inoculation. Nitrogen concentrations of the rice plants were determined by Kjeldahl method.

\subsection{Bacterial Genomic DNA Extraction}

The selected bacterial isolates were grown in nutrient agar and incubated at $30^{\circ} \mathrm{C}$ for $48 \mathrm{hr}$. Bacterial cells were harvested in $1.5 \mathrm{ml}$ microcentrifuge tube. The bacteria were washed for 3 times with Tris EDTA buffer $\mathrm{pH} 8.0$ and centrifuged at $6000 \mathrm{rpm}$ for $3 \mathrm{~min}$. Bacterial cells were lysed with $400 \mu \mathrm{l}$ of $10 \%$ SDS under incubation at $37^{\circ} \mathrm{C}$ for $30 \mathrm{~min}$. Protein was precipitated with chloroform: isoamyl alcohol $(24: 1)$ from the solution. Bacterial DNA was precipitated by adding cold isopropanol and centrifuged at $14,000 \mathrm{rpm}, 4^{\circ} \mathrm{C}$ for $3 \mathrm{~min}$. The DNA pellet was washed twice with $70 \%$ ethanol and suspended in $1 \mathrm{X}$ TE buffer at $-20^{\circ} \mathrm{C}$ (Brunel et al., 1997).

\subsection{PCR Amplification and Phylogenetic Analysis of $16 \mathrm{~S}$ rRNA Gene}

Universal primers pairs of 27F (5'-AGAGTTTGATCMTGGCTCAG-3') with 1525R (5'-AAGGAGGTGWTCC ARCC-3') and 357F (5'-CTCCTACGAGGCAGG-3') with 1392R (5'-ACGGGCGGTGTGTAC-3') were used for amplification of 16S rRNA gene fragments. Total PCR reaction mixture contained 2x PCR Master mix (i-Taq) 10 $\mu 1$, template DNA $2 \mu \mathrm{l}, 10 \mathrm{pmol} / \mu \mathrm{l}$ of each primer $1 \mu \mathrm{l}$ and distilled water $6 \mu \mathrm{l}$. For PCR cycle, an initial denaturation at $94^{\circ} \mathrm{C}$ for $2 \mathrm{~min}$, each thermal cycling was followed by 30 cycles: denaturation at $94^{\circ} \mathrm{C}$ for $30 \mathrm{~s}$, annealing at $55^{\circ} \mathrm{C}$ for $30 \mathrm{~s}$, extension at $72^{\circ} \mathrm{C}$ for $30 \mathrm{~s}$ and final extension at $72^{\circ} \mathrm{C}$ for $7 \mathrm{~min}$. PCR products were determined on 1\% agarose gel (Brunel et al., 1997). The 16S rRNA genes were sequenced at Biobasic Inc. in Canada. The similarities of nucleotide were compared with those at the National Center for Biotechnology Information (NCBI) by BLAST program. Phylogenetic tree was analysed using BioEdit with MEGA 4 version 4.0.2 (Bootstrap=1000) (Tamura et al., 2007).

\section{Results and Discussion}

One hundred and twenty-three isolates of endophytic bacteria were collected on NFA. The number of endophytic bacteria in roots, stems and leaves of rice seedlings from farmers' field that had never received $\mathrm{N}$ fertilizer ranged from $3.0 \times 10^{2}$ to $2.9 \times 10^{8}$ cells/g fresh weight (Table 1 ). The population of endophytic bacteria was found to vary in density with rice variety and parts of the plant. The number of endophytic bacteria that could grow in $\mathrm{N}$-free medium was highest in the leaves and roots of Chai Nat 1 , a modern rice variety. Martin \& ReinholdHurek (2002) reported that high density of $\mathrm{N}$ fixing bacteria were found in plants growing in cultivated field without chemical fertilizer. Acetylene reduction assay (ARA) confirmed that isolates of the endophytic bacteria from rice had nitrogenase activity (data not shown). Seven isolates of the bacteria with highest nitrogenase activity, in the range of 26.0-119.9 $\mathrm{nmol} \mathrm{C}_{2} \mathrm{H}_{4} / \mathrm{mg}$ protein/h, were chosen for identification (Table 2). This range 
of nitrogenase activity was comparable to $31.7-92.0 \mathrm{nmol} \mathrm{C}_{2} \mathrm{H}_{4} / \mathrm{mg}$ cell/h reported by Sugitha and Kumar (2009) for endophytic bacteria from the rhizosphere soil, rhizoplane, roots and stems of rice growing in Tamil Nadu State, India. In this experiment, the endophytic bacteria with the highest nitrogenase activity were from either stems or roots of modern high yield varieties Chai Nat 1 (CS5 from stems; CR9 from roots) and Suphan Buri 1 (SS5 and SS6 from stems; SR1 from roots) and from the roots of local variety Muey Nong 25 (25R14 and 25R2) isolated from the stems of Chai Nat 1.

Table 1. Number of endophytic bacteria in roots, stems and leaves from rice varieties

\begin{tabular}{lccc}
\hline \multirow{2}{*}{ Rice varieties } & \multicolumn{3}{c}{ Endophytic bacteria (cells/g fresh weight) } \\
\cline { 2 - 4 } & Roots & Stems & Leaves \\
\hline Muey Nong 24 & $1.8 \times 10^{5} \mathrm{c}$ & $1.7 \times 10^{6}$ & $2.3 \times 10^{5} \mathrm{c}$ \\
Muey Nong 25 & $3.1 \times 10^{3} \mathrm{c}$ & $3.0 \times 10^{2}$ & $6.1 \times 10^{2} \mathrm{c}$ \\
Chai Nat 1 & $1.0 \times 10^{8} \mathrm{~b}$ & $8.4 \times 10^{3}$ & $2.9 \times 10^{8} \mathrm{a}$ \\
Suphan Buri 1 & $2.5 \times 10^{5} \mathrm{c}$ & $2.9 \times 10^{5}$ & $1.5 \times 10^{5} \mathrm{c}$ \\
Pathum Thani 1 & $1.8 \times 10^{5} \mathrm{c}$ & $2.3 \times 10^{5}$ & $2.4 \times 10^{3} \mathrm{c}$ \\
\hline Effect by F-test & $P<0.05$ & $\mathrm{NS}$ & $P<0.05$ \\
\hline
\end{tabular}

Different letters designate significant difference within column by Duncan's Multiple Range Test at $P \leq 0.05$.

NS $=$ Not significant at $P=0.05$.

Table 2. Nitrogenase activity of selected endophytic bacterial isolates from rice

\begin{tabular}{llcc}
\hline $\begin{array}{l}\text { Bacterial } \\
\text { isolates }\end{array}$ & Rice varieties & Plant parts & $\begin{array}{c}\text { Nitrogenase activity } \\
\left(\mathrm{nmol} \mathrm{C} \mathrm{H}_{4} / \mathrm{mg} \text { protein/h) }\right.\end{array}$ \\
\hline CS5 & Chai Nat 1 & Stem & $119.9 \mathrm{a}$ \\
CR9 & Chai Nat 1 & Roots & $44.6 \mathrm{ab}$ \\
$25 \mathrm{R} 2$ & Muey Nong 25 & Roots & $29.2 \mathrm{~b}$ \\
$25 \mathrm{R} 14$ & Muey Nong 25 & Roots & $84.5 \mathrm{ab}$ \\
SR1 & Suphan Buri 1 & Roots & $26.0 \mathrm{~b}$ \\
SS5 & Suphan Buri 1 & Stem & $36.5 \mathrm{~b}$ \\
SS6 & Suphan Buri 1 & Stem & $61.0 \mathrm{ab}$ \\
\hline Effect by F-test & & & $P<0.05$ \\
\hline
\end{tabular}

Different letters designate significant difference within column by Duncan's Multiple Range Test at $P \leq 0.05$.

Amplification of 16S rRNA gene and phylogenetic analysis of bacterial isolate CS5 indicated that it was in the species of Burkholderia cepacia with bootstrap 99\% (Figure 1). Singh et al. (2006) isolated Bukholderia from the rice roots. Procópio et al. (2009) isolated Bu. cepacia from stems of Eucalyptus spp. which was able to control Magnaporthe grisea, Fusarium moniliforme and Rhizoctonia solani. Govindarajan et al. (2007) determined the ability to reduce acetylene by endophytes from different sources and found that Bu. vietnamiensis (MGK3) had highest nitrogenase activity on glycerol, followed by mannitol and sucrose. 


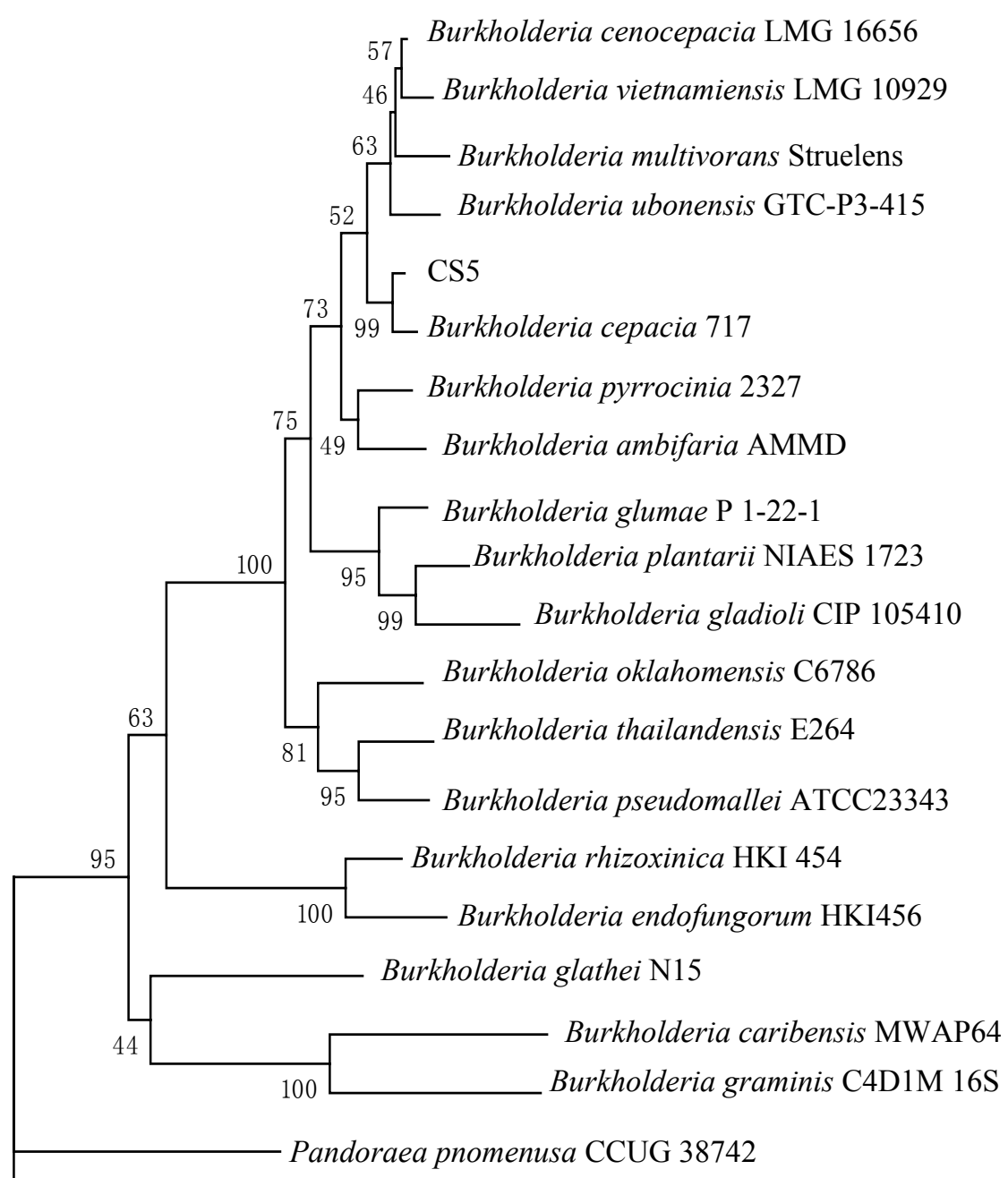

Leptothrix mobilis Feox-1

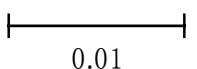

Figure 1. Phylogenetic tree based on 16S rRNA sequences of the endophytic bacterial isolate CS5

Bacterial isolates CR9, SS5 and SS6 showed similarity to the genus Citrobacter. Their close phylogenetic affinity suggested that these three isolates could be in the same species (Figure 2). However, the species of these isolates should be further identified. Tan et al. (2009) isolated bacteria closely related to C. amalonaticus from roots of $O$. rufipogon which showed nitrogenase activity in the range of 3.31- 36.89 $\mu \mathrm{mol} \mathrm{C}_{2} \mathrm{H}_{4} / \mathrm{ml} / \mathrm{h}$. The isolates, $25 \mathrm{R} 14$ and SR1 were similar to Bacillus amyloliquefaciens, and 25R2 was similar to B. thuringiensis (Figure 3). Praça et al. (2012) reported that $B$. thuringiensis was found in soil, water, plants and dead insects. Cabbage seedlings inoculated with $B$. thuringiensis were detected inside roots and leaves of plants. It is a very important bacterium used as a biological control agent for insects. B. amyloliquefaciens is a bacterium used as a biological control agent of Xanthomonas campestris pv. campestris causing black root of cabbage and improve growth of the control plants (Wulff et al., 2002). 


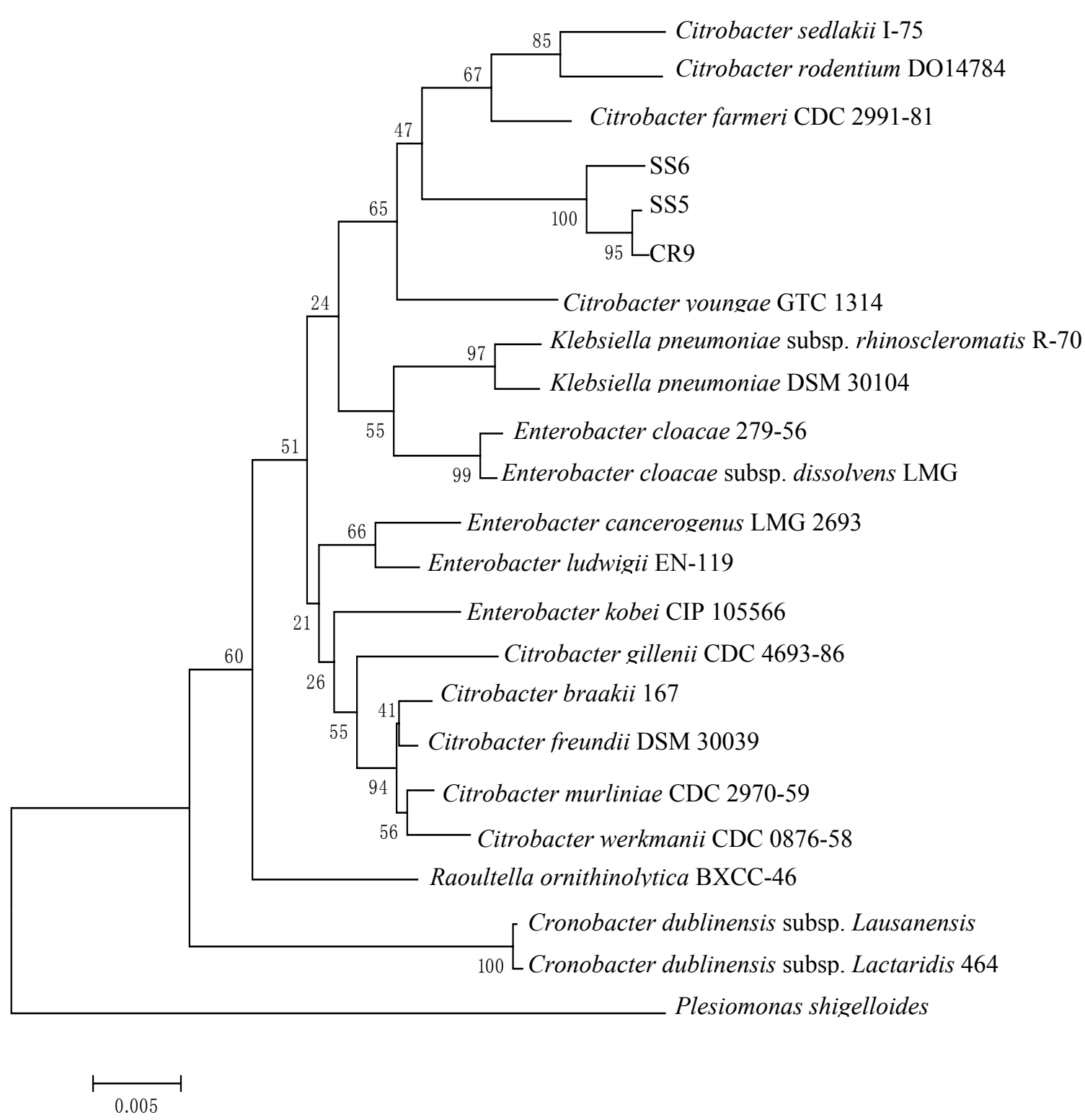

Figure 2. Phylogenetic tree based on 16S rRNA sequences of the endophytic bacterial isolates SS5, SS6 and CR9 


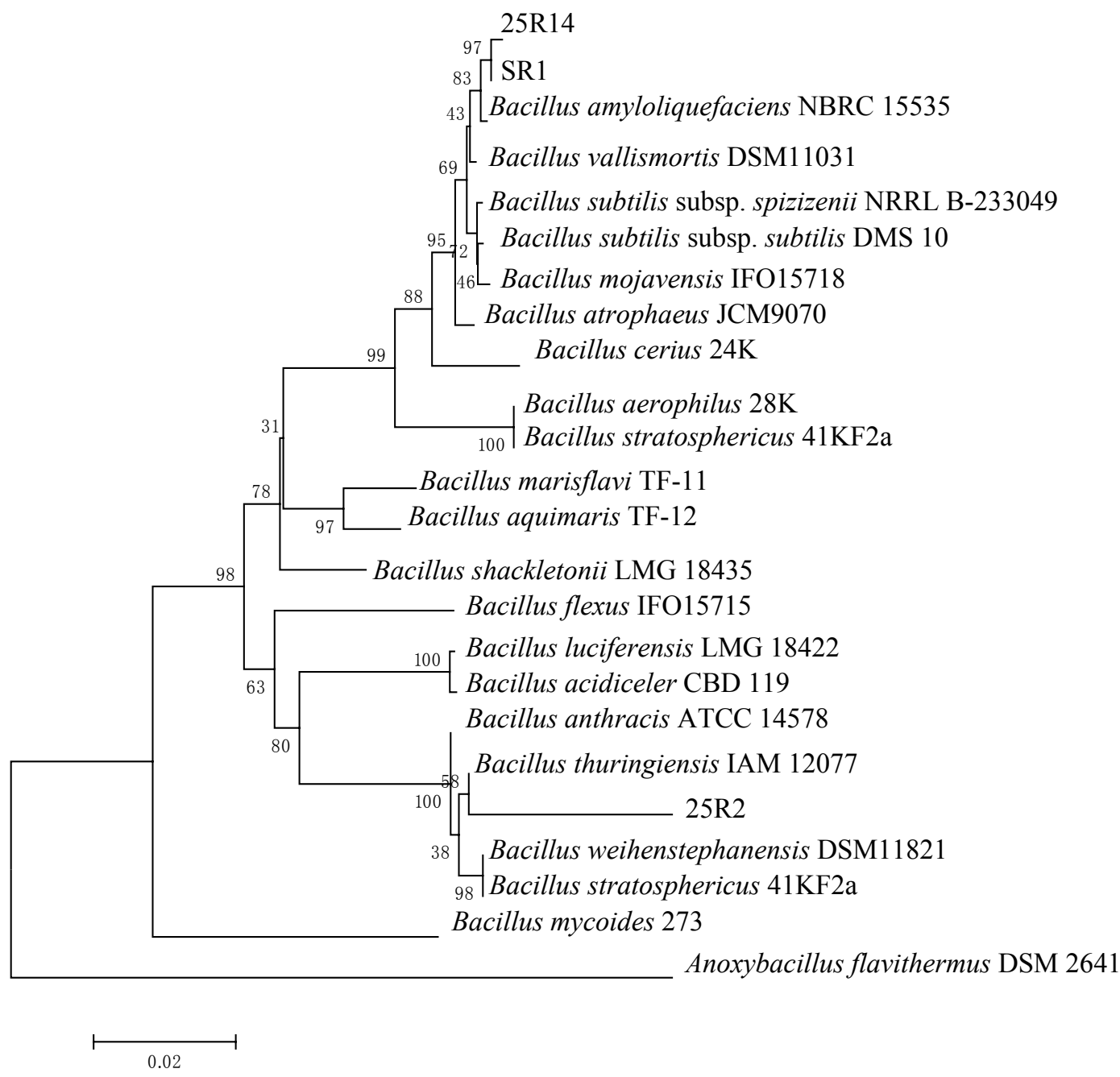

Figure 3. Phylogenetic tree based on 16S rRNA sequences of the endophytic bacteria 25R14, SR1 and 25R2

Some of the selected endophytic bacteria contributed $\mathrm{N}$ supply to the rice seedlings which was evident in leaf chlorophyll content (Table 3) and root N (Table 4). Chlorophyll meter has been effectively used to determineN status of rice, wheat (Singh et al., 2002) and other crops (Swiader \& Moore, 2002; Fontes \& de Araujo, 2006) in the youngest emerged blades (YEB) of rice plants (Muey Nong 24) the treatments were measured by chlorophyll meter (SPAD 502) every 7 days. It was shown that the inoculated treatments increased chlorophyll contents in YEB compared with the uninoculated control plant in 56 days (Table 3). For detection of nitrogen concentrations, the rice plants inoculated with Bu. cepacia (CS5) and Citrobacter sp. (CR9) had the highest nitrogen concentration in roots and higher than uninoculated control plants (Table 4). Potential of nitrogen fixing bacteria inoculated in rice grown in nitrogen free medium may be limited in carbon and nitrogen sources for initial growth. Inoculation with endophytic bacteria increased biomass of the rice plants (Table 5), but it was not significantly higher than the uninoculated rice plants. Chiarini et al. (1998) reported that sorghum inoculated with Bu. cepacia resulted in improved root biomass. Govindarajan et al. (2007) inoculated Bu. vietnamiensis (MGK3) to rice plants and showed that the bacterium could increase the grain yield of rice by $5.6-12.6 \%$.

Application of nitrogen fixing endophytic bacteria may be potential biofertilizer integrated with green manure or compost fertilizer for rice production in organic farming. Therefore, further inoculum production of the nitrogen fixing endophytic bacteria and the optimum soil condition should be investigated. 
Table 3. Chlorophyll content in young emerged blade (YEB) of rice variety Muey Nong 24

\begin{tabular}{lllll}
\hline \multirow{2}{*}{ Bacterial isolates } & \multicolumn{4}{c}{ Chlorophyll content in YEB (SPAD unit) } \\
\cline { 2 - 5 } & 7 & 28 & 56 & 84 \\
\cline { 2 - 5 } & 18.2 & 17.79 & $23.8 \mathrm{c}$ & $20.2 \mathrm{c}$ \\
\hline Uninoculated control & 18.85 & 17.45 & $25.4 \mathrm{ab}$ & $20.4 \mathrm{c}$ \\
Bu. cepacia (CS5) & 18.2 & 17.3 & $24.0 \mathrm{c}$ & $22.3 \mathrm{ab}$ \\
B. amyloliquefaciens (25R14) & 18.5 & 16.7 & $24.4 \mathrm{ab}$ & $22.1 \mathrm{~b}$ \\
B. amyloliquefaciens (SR1) & 19.15 & 18.1 & $25.8 \mathrm{a}$ & $22.9 \mathrm{ab}$ \\
B. thuringiensis (25R2) & 18.43 & 17.0 & $24.7 \mathrm{ab}$ & $23.9 \mathrm{a}$ \\
Citrobacter (SS5) & 19.2 & 17.3 & $25.1 \mathrm{ab}$ & $22.9 \mathrm{ab}$ \\
Citrobacter (SS6) & 17.8 & 17.7 & $24.2 \mathrm{ab}$ & $22.3 \mathrm{ab}$ \\
Citrobacter (CR9) & $\mathrm{NS}$ & $\mathrm{NS}$ & $P<0.05$ & $P<0.05$ \\
\hline Effect by F-test & & &
\end{tabular}

Different letters designate significant difference within column by Duncan's Multiple Range Test at $P \leq 0.05$.

NS $=$ Not significant at $P=0.05$.

Table 4. Nitrogen concentration in roots and shoot of rice (Muey Nong 24)

\begin{tabular}{lcc}
\hline \multirow{2}{*}{ Bacrerial isolates } & \multicolumn{2}{c}{ Nitrogen concentration (\%) } \\
\cline { 2 - 4 } & Roots & Shoots \\
\hline Uninoculated control & $0.74 \mathrm{~b}$ & 0.70 \\
Bu. cepacia (CS5) & $0.93 \mathrm{a}$ & 0.74 \\
B. amyloliquefaciens (25R14) & $0.80 \mathrm{ab}$ & 0.75 \\
B. amyloliquefaciens (SR1) & $0.70 \mathrm{~b}$ & 0.72 \\
B. thuringiensis (25R2) & $0.80 \mathrm{ab}$ & 0.74 \\
Citrobacter (SS5) & $0.82 \mathrm{ab}$ & 0.71 \\
Citrobacter (SS6) & $0.75 \mathrm{~b}$ & 0.69 \\
Citrobacter (CR9) & $0.90 \mathrm{a}$ & 0.68 \\
\hline Effect by F-test & $P<0.05$ & $\mathrm{NS}$
\end{tabular}

Different letters designate significant difference within column by Duncan's Multiple Range Test at $P \leq 0.05$.

NS $=$ Not significant at $P=0.05$.

Table 5. Fresh and dry weight of rice plants variety Muey Nong 24 inoculated with different isolates of $\mathrm{N}$ fixing endophytic bacteria

\begin{tabular}{lllll}
\hline \multirow{2}{*}{ Inoculation } & \multicolumn{2}{l}{ Fresh weight (g/plant) } & \multicolumn{2}{l}{ Dry weight (g/plant) } \\
\cline { 2 - 5 } & Roots & Shoots & Roots & Shoots \\
\hline Uninoculated control & $2.0 \mathrm{~d}$ & $3.3 \mathrm{bc}$ & 0.28 & 0.63 \\
Bu. cepacia (CS5) & $2.5 \mathrm{~cd}$ & $3.9 \mathrm{ab}$ & 0.30 & 0.67 \\
B. amyloliquefaciens (25R14) & $2.2 \mathrm{~d}$ & $3.9 \mathrm{ab}$ & 0.28 & 0.63 \\
B. amyloliquefaciens $(\mathrm{SR} 1)$ & $2.5 \mathrm{~cd}$ & $4.2 \mathrm{a}$ & 0.32 & 0.67 \\
B. thuringiensis (25R2) & $2.4 \mathrm{~d}$ & $3.6 \mathrm{ab}$ & 0.29 & 0.69 \\
Citrobacter (SS5) & $2.5 \mathrm{~cd}$ & $4.0 \mathrm{ab}$ & 0.29 & 0.67 \\
Citrobacter (SS6) & $2.4 \mathrm{~d}$ & $4.2 \mathrm{a}$ & 0.25 & 0.66 \\
Citrobacter (CR9) & $2.0 \mathrm{~d}$ & $4.0 \mathrm{ab}$ & 0.25 & 0.66 \\
\hline Effects by F-test & $P<0.05$ & $P<0.05$ & $\mathrm{NS}$ & $\mathrm{NS}$ \\
\hline
\end{tabular}

Difference letters designate significant difference within column by Duncan's Multiple Range Test at $P \leq 0.05$. NS $=$ Not significant at $P=0.05$. 


\section{Acknowledgements}

The authors would like to acknowledge for financial support from the National Research Universities Program of Thailand Commission on Higher Education. We wish to thank the Department of Biology, Faculty of Science, Chiang Mai University and the Department of Plant Science and Natural Resources for the research facilities.

\section{References}

Bhattacharjee, R. B., Singh, A., \& Mukhopadhyay, S. N. (2008). Use of nitrogen-fixing bacteria as biofertiliser for non-legumes: prospects and challenges. Applied Microbiology and Biotechnology, 80, 199-209. http://dx.doi.org/10.1007/s00253-008-1567-2

Boddey, R. M., Urquiaga, S., Alves, B. J. R., \& Reis, V. (2003). Endophytic nitrogen fixation in sugarcane: present knowledge and future applications. Plant and Soil, 252, 139-149. http://dx.doi.org/10.1023/A:1024152126541

Brunel, B., Givaudan, A., Lanois, A., Akhurst, R. J., \& Boemare, N. (1997). Fast and accurate identification of Xenorhabdus and Photorhabdus species by restriction analysis of PCR-amplified 16S rRNA genes. Applied and Environmental Microbiology, 63, 574-580. http://aem.asm.org/ on June 4, 2013 by guest

Chiarini, L., Bevivino, A., Tabacchioni, S., \& Dalmastri, C. (1998). Inoculation of Burkholderia cepacia, Pseudomonas fluorescens and Enterobacter sp. on Sorghum bicolor: root colonization and plant growth promotion of dual strain inocula. Soil Biology and Biochemistry, 30, 81-87. http://dx.doi.org/10.1016/S0038-0717(97)00096-5

Choudhury, A. T. M. A., \& Kennedy, I. R. (2004). Prospects and potentials for systems of biological nitrogen fixation in sustainable rice production. Biology and Fertility of Soils, 39, 219-227. http://dx.doi.org/10.1007/ s00374-003-0706-2

Craswell, E. T., De Datta, S. K., Obcemea, W. N., \& Hartantyo, M. (1981). Time and mode of nitrogen fertilizer application to tropical wetland rice. Fertilizer Research, 2, 247-259. http://dx.doi.org/10.1007/BF01050197

Engelhard, M., Hurek, T., \& Reinhold-Hurek, B. (2000). Preferential occurrence of Diazotrophic endophytes, Azoarcus spp., in wild rice species and land races of Oryza sativa in comparison with modern races. Environmental Microbiology, 2, 131-141. http://dx.doi.org/10.1046/j.1462-2920.2000.00078.x

FAOSTAT. (2013). FAO Statistical Yearbooks-World food and agriculture. Rome, Italy: Food and Agriculture Organization of the United Nations.

Fontes, P. C. R., \& de Araujo, C. (2006). Use of a chlorophyll meter and plant visual aspect for nitrogen management in tomato fertigation. Journal of Applied Horticulture, 8, 8-11.

Govindarajan, M., Balandreau, J., Kwon, S. W., Weon, H. Y., \& Lakshminarasimhan, C. (2007). Effects of the inoculation of Burkholderia vietnamensis and related endophytic diazotrophic bacteria on grain yield of rice. Microbial Ecology, 55, 21-37. http://dx.doi.org/10.1007/s00248-007-9247-9

Gyaneshwar, P., James, E. K., Mathan, N., Reddy, P. M., Reinhold-Hurek., B., \& Ladha, J. (2001). Endo-phytic colonization of rice by a diazotrophic strain of Serratia marcescens. Bacteriology, 183, 2634-2645. http://dx.doi.org/10.1128/JB.183.8.2634-2645.2001

Holt, J. G., Krieg, N. R., Sneath, P. H. A., Staley, J. T., \& Williams, S. T. (1994). Bergey's Manual of Determinative Bacteriology (9th ed.). Baltimore, MD: The William \& Wilkin's Company.

James, E. K., Gyaneshwar, P., Mathan, N., Barraquio, W. L., Reddy, P. M., Iannetta, P. M., , ... Ladha, J. K. (2002). Infection and colonization of rice seedlings by the plant growth-promoting bacterium Herbaspirillium seropedica Z67. Molecular Plant-Microbe Interactions, 15, 894-906. http://dx.doi.org/10.1094/MPMI.2002.15.9.894

James, E. K., Olivares, F. L., Baldani, J. I., \& Döbereiner, J. (1997). Herbaspirillum, an endophytic diazotroph colonizing vascular tissue in leaves of Sorghum bicolor L. Moench. Journal of Experimental Botany, 48, 785-798. http://dx.doi.org/10.1093/jxb/48.3.785

Lee, K. K., \& Yoshida, T. (1997). An assay technique of measurement of nitrogenase activity in root zone of rice for varietal screening by the acetylene reduction method. Plant and Soil, 46, 127-134. http://dx.doi.org/10.1007/BF00693119 
Lima, E., Boddey, R. M., \& Döbereiner, J. (1987). Quantification of biological nitrogen fixation associated with sugar cane using a ${ }^{15} \mathrm{~N}$ aided nitrogen balance. Soil Biology and Biochemistry, 19, 165-170. http://dx.doi.org/10.1016/0038-0717(87)90077-0

Martin, D. E., \& Reinhold-Hurek, B. (2002). Distinct roles of Pll-like signal transmitter proteins and amtB inregulation of nif gene expression, nitrogenase activity, and post-translation modification of $\mathrm{NifH}$ in Azoarcus BH72. Bacteriology, 184, 2551-2559. http://dx.doi.org/10.1128/JB.184.10.2699-2708.2002

McDonald, M. P., Galwey, N. W., Ellneskog, S. P., \& Colmer, T. D. (2001). Evaluation of Lophpyrum elongatum as a source of genetic diversity to increase the water logging tolerance of hexapoid wheat (Triticum aestivum). New Phytologist, 151, 369-380. http://dx.doi.org/10.1046/j.1469-8137.2001.00183

Praça, L. B., Gomes, A. C. M., Cabral, G., Martins, E. S., Sujii, E. H., \& Monnerat, R. M. (2012). Endophytic colonization by Brazilian strains of Bacillus thuringiensis on cabbage seedlings grown in vitro. Biopublisher, $3,11-19$.

Procópio, R. E. L., Araújo, W. L., Maccheroni, W. J., \& Azevedo, J. L. (2009). Characterization of an endophytic bacterial community associated with Eucalyptus spp. Genetics and Molecular Research, 4, 1408-1422. http://dx.doi.org/10.4238/vol8-4gmr691

Singh, B., Singh, Y., Ladha, J. K., Bronson, K. F., Balasubramanian, V., Singh, J., \& Khind, C. S. (2002). Chlorophyll meter- and leaf color chart-based nitrogen management for rice and wheat in Northwestern India. Agronomy Journal, 94, 821-829. http://dx.doi.org/10.2134/agronj2002.8210

Singh, R. K., Mishra, R. P. N., Jaiswal, H. K., Kumar, V., Pandey, S. P., Rao, S. B., \& Annapurna, K. (2006). Isolation and identification of natural endophytic rhizobia from rice (Oryza sativa L.) through rDNA PCR-RFLP and sequence analysis. Current Microbiology, 52, 117-122. http://dx.doi.org/10.1007/s00284-005-0136-5

Stolzfus, J. R., So, R., Malarvithi, P. P., Ladha, J. K., \& de Bruiji, F. J. (1997). Isolation of endophytic bacteria from rice and assessment of their potential for supplying rice with biologically fixed nitrogen. Plant and Soil, 194, 25-36. http://dx.doi.org/10.1023/A:1004298921641

Sugitha, T. C. K., \& Kumar, K. (2009). Identification of nif genes of heterotrophic and endophytic diazotrophs associated with rice (Oryza sativa L.,) by targeted DNA finger printing. African Journal of Biotechnology, 8, 6249-6252. http://www.academicjournals.org/AJB

Swiader, J. M., \& Moore, A. (2002). SPAD-chlorophyll response to nitrogen fertilization and evaluation of nitrogen status in dryland and irrigated pumpkins. Journal of Plant Nutrition, 25, 1089-1100. http://dx.doi.org/10.4236/ajps.2012.311187

Tamura, K., Dudley, J., Nei, M., \& Kumar, S. (2007). MEGA4: Molecular evolutionary genetics analysis (MEGA) software version 4.0. Molecular Biology and Evolution, 24, 1596-1599. http://www.ncbi.nlm.nih.gov/pubmed/17488738

Tan, Z. Y., Peng, G. X., Xu, P. Z., Ai, S. Y., Tang, S. H., Zhang, G. X., \& Zeng, F. Y. (2009). Diversity and high nitrogenase activity of endophytic diazotrophs isolated from Oryza rufipogon Griff. Chinese Science Bulletin, 54, 2839-2848. http://dx.doi.org/10.1007/s11434-009-0408-8

Wulff, E. G., Mguni, C. M., Mansfeld-Giese, K., Fels, J. M., Lubeck, M., \& Hockenhull, J. (2002). Biochemical and molecular characterization of Bacillus amyloliquefaciens, B. subtilis and B. pumilus isolates with distinct antagonistic potential against Xanthomonas campestris pv. campestris. Plant Pathology, 51, 74-584. http://dx.doi.org/10.1046/j.1365-3059.2002.00753.x

Yoshida, S. (1981). Fundamentals of Rice Crop Science. Los Baños, Philippines: International Rice Research Institute.

\section{Copyrights}

Copyright for this article is retained by the author(s), with first publication rights granted to the journal.

This is an open-access article distributed under the terms and conditions of the Creative Commons Attribution license (http://creativecommons.org/licenses/by/3.0/). 